\title{
Olive oil quality influenced by biostimulant foliar fertilizers
}

\section{Imen Zouari ${ }^{1,2, *}$, Beligh Mechri ${ }^{3}$, Meriem Tekaya ${ }^{3}$, Olfa Dabbaghi $^{3}$, Imed Cheraief ${ }^{3}$, Amel Mguidiche ${ }^{1}$, Khouloud Annabi ${ }^{1,2}$, Foued Laabidi $^{1}$, Faouzi Attia ${ }^{4}$, Mohamed Hammami $^{3}$ and Mouna Aïachi Mezghani ${ }^{1}$}

\author{
${ }^{1}$ Research Laboratory. Durability of Oleiculture in Semi-Arid and Arid Regions. \\ Amelioration of the Productivity of Olive Tree and Quality of Products. Olive Tree \\ Institute Sousse. Ibn Khaldoun Street, B. P. 14. 4061. Sousse, Tunisia. \\ ${ }^{2}$ Higher Agronomic Institute of Chott Mariem. IRESA-University of Sousse, B. P. 47. \\ 4042. Chott Mariem. Sousse, Tunisia. \\ ${ }^{3}$ Biochemical Laboratory. USCR Mass Spectrometry. LAB-NAFS/LR12ES05 \\ "Nutrition - Functional Foods and Vascular Health". Faculty of Medicine of \\ Monastir. Avicenne Street, 5019. Monastir, Tunisia. \\ ${ }^{4}$ Agronomic Research Team. Agronutrition. Orchidée Street, 3. 31390 ; Carbonne, \\ France.
}

\begin{abstract}
Foliar fertilization has been used as an important tool to meet the tree nutrient demand and to be an environmental beneficial with the use of little quantities. Actually modern fruit trees physiology is focused on the stimulation of plant cell development and fruit production using biostimulants. In olive trees, few products have been used for improving oil quality. For this purpose, two biostimulants products have been tested and used simple or combined with a third product rich in nitrogen. The treatments were classified to: T1 (rich in nitrogen) and biostimulants treatments as following T2 (combination of boron, magnesium, sulfur and manganese associated with seaweed) TNi (biostimulant combining a protein extract with a calcium base), T12 (combined application of T1 and T2) and finally $\mathrm{T} 12 \mathrm{Ni}$ (combined application of T1, T2 and TNi) with a control treatment CON (without foliar fertilization). All these foliar nutrients were sprayed during two successive years on trees issued of Chemlali cultivar cultivated in rain-fed conditions of central Tunisia. Biochemical parameters of the olive oil, like physiochemical characteristics, fatty acid profile total polyphenols, ortho-diphenols, chlorophyllic and carotenoids pigments were analyzed annually after the application of these foliar compounds. All the olive oils issued from the treatments were classified as extra virgin and the physiochemical parameters were sensitive to foliar fertilization except for some parameters. Quantitative changes were observed in the pool of the fatty acids composition and the treatment TNi (rich in
\end{abstract}

Received

November 21, 2019

Accepted

March 11, 2020

Available on line on

March 20, 2020

Released

April 30, 2020

Full Text Article

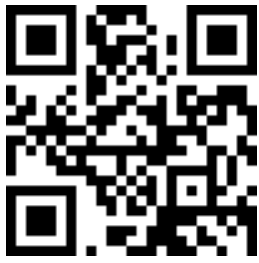

다 0000-0001-5792-5176 Imen Zouari 
calcium) increased significantly the percentage of the monounsaturated fatty acid (MUFA) C18:1 as well as the ratios C18:1/C18:2 and MUFA/polyunsaturated fatty acids (PUFA) during the first year of experimentation. This treatment induced also an increase in the total polyphenols concentration. An annual variation between treatments has been observed according the polyphenols concentration and othodiphenols which can be influenced by climatic conditions principally in rain-fed conditions. This study highlighted the effect of the nutrient availability cumulated after two years of foliar application on the olive oil quality.

Keywords: Acidic profile; Antioxidants; Foliar fertilization; Nutrients; Olive oil.

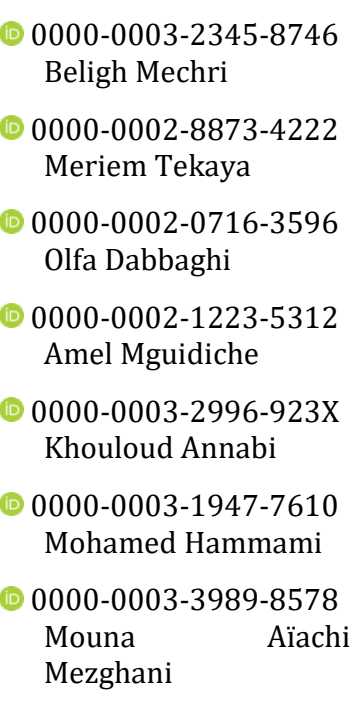

\section{Introduction}

Olive oil is considered the main fat source of the Mediterranean diet, and it is appreciated for its characteristics such as: aroma, taste, color, and nutritive properties that are distinguishable from other vegetable oils (Servili et al., 2014).

Olive oil consumption is increasing and is associated with a decreased risk of cardiovascular disease, cancer risk (Nicolaïew et al., 1998; Covas et al., 2006) and obesity (Pacheco et al., 2006). In fact, due to its high levels of monounsaturated fatty acids (mainly oleic acid), the olive oil has specific roles in the prevention of inflammatory and degenerative diseases like Alzheimer's disease (Scarmeas et al., 2006). It contains also a group of minor compounds with high antioxidant activity. Among these compounds, can be highlighted the phenolic compounds, which have nutritional effects, protect the oils against oxidation and are related with some sensorial characteristics.

Many factors may affect the fruit production and physiology and consequently the olive oil quality, like climatic conditions, cultivar, agronomic practices, fruit ripening and harvest conditions (Uceda et al., 2004; Giuffrè, 2013; Giuffrè, 2014). Within the agronomical practices, it's well known that appropriate nutrient management is crucial for optimizing crop production (Tanou et al., 2017).

It is expected that the levels of available nutrients may influence plant growth, fruit production and oil yield and quality (Fernández-Escobar et al., 2006; Morales-Sillero et al., 2007; Erel et al., 2008). Foliar spraying of nutrients is known to be helpful to satisfy plant requirement and is a convenient method to apply fertilizers in small amounts (Inglese et al., 2002).

Many researchers have focused on studying the effect of nutrient availability on the plant growth, fruit production, fruit set, oil yield and quality (Jasrotia et al., 1999; Fernández-Escobar et al., 2006; Morales-Sillero et al. 2007; Erel et al., 2008). Nitrogen is a very important element for the olive tree and it is required in very high amounts for the accomplishment of vegetative growth and fruit production. Therefore this element is widely used in fertilization programs for olive orchards (Fernández-Escobar et al., 2014). Other mineral elements like boron, iron, zinc, manganese, copper and molybdenum are required in small amounts by the olive tree but each of them is essential (Kailis et al., 2007). Boron is known to be involved in photosynthesis, N-fixation and other biochemical activities (Cakmak and Marschner, 1988). 
New biostimulants fertilizers are nowadays used to enhance nutrient uptake and stimulate stress-related tolerance mechanisms (Kunichki et al., 2010). They could be defined as products containing substance(s) and/or micro-organisms whose function when applied to plants or the rhizosphere is to stimulate natural processes to enhance/benefit nutrient uptake, nutrient efficiency, tolerance to abiotic stress, and crop quality (EBIC, 2013).

However, little is known about the effect of foliar sprays of nutrients on the olive oil quality. Some authors have reported the use of the foliar fertilization and its effect on olive oil quality (Tekaya et al., 2012, 2013; Mahmoud et al., 2017). Several works have demonstrated that foliar sprays of biostimulants on olive tree improved oil quality characteristics (Chouliaras et al., 2009), mineral content (Zulaikha, 2013) and fruit yield (Chouliaras et al., 2009).

The focus of this study was to analyze the cumulative effect of three foliar fertilizers (nitrogen treatment and biostimulants) used during two consecutive growing seasons on the most common Tunisian cultivar Chemlali cultivated under rain-fed conditions in Tunisia. This study has focused on the effects of these fertilizers used simple or combined on quality parameters, fatty acid profile, antioxidants content, Chlorophyll and beta-carotene content of the olive oil.

\section{Materials and methods}

\section{Site description}

This study was carried out through two crop seasons 2014 and 2015 in an orchard with mature olive trees Olea europaea L. cultivar Chemlali, located in Monastir Tunisia $\left(35^{\circ} 75^{\prime} \mathrm{N}, 10^{\circ} 71^{\prime} \mathrm{E}, 18 \mathrm{~m}\right.$ altitude). The trees are grown under rain-fed conditions and were planted at a density of 100 plants/ha. Chemlali, the principal cultivar in Tunisia, is principally destined for olive oil extraction. The climate is typical Mediterranean. Weather variables were recorded regularly by a meteorological station situated near the olive orchard. Soil characteristics are: sandy and alkaline, available phosphorus (P205): 0.81 ppm $(0-30 \mathrm{~cm}$ of the soil depth) and $0.39 \mathrm{ppm}(30-60 \mathrm{~cm})$, and exchangeable potassium (K20): $0.03 \%(0-30 \mathrm{~cm})$ and $0.08 \%(30-60 \mathrm{~cm})$.

For the two studied years, the monthly variations in temperature and rainfall are presented in the Figure 1a and 1b. The annual rainfall for 2014 and 2015 was $329.69 \mathrm{~mm}$ and $322.1 \mathrm{~mm}$ respectively, concentrated mainly from autumn to spring. Concerning the average temperature of each year, it was equal to $20.08{ }^{\circ} \mathrm{C}$ and $20.01{ }^{\circ} \mathrm{C}$ for 2014 and 2015 , respectively.

The cumulated rainfall during the autumn season (from September until harvest) is presented in Table 1 . The value was higher in the year 2014 than the following year (2015) and was equal to $106.52 \mathrm{~mm}$.

Table 1. Cumulated rainfall in autumn season in the experimental orchard.

\begin{tabular}{ccccc}
\hline Year & September & October & $\begin{array}{c}\text { November } \\
\text { (until harvest) }\end{array}$ & Total (mm) \\
\hline 2014 & 20.51 & 58.31 & 27.70 & 106.52 \\
\hline 2015 & 33.96 & 47.14 & 6.55 & 87.65 \\
\hline
\end{tabular}

Braz. J. Biol. Sci., 2020, Vol. 7, No. 15, p. 3-18. 


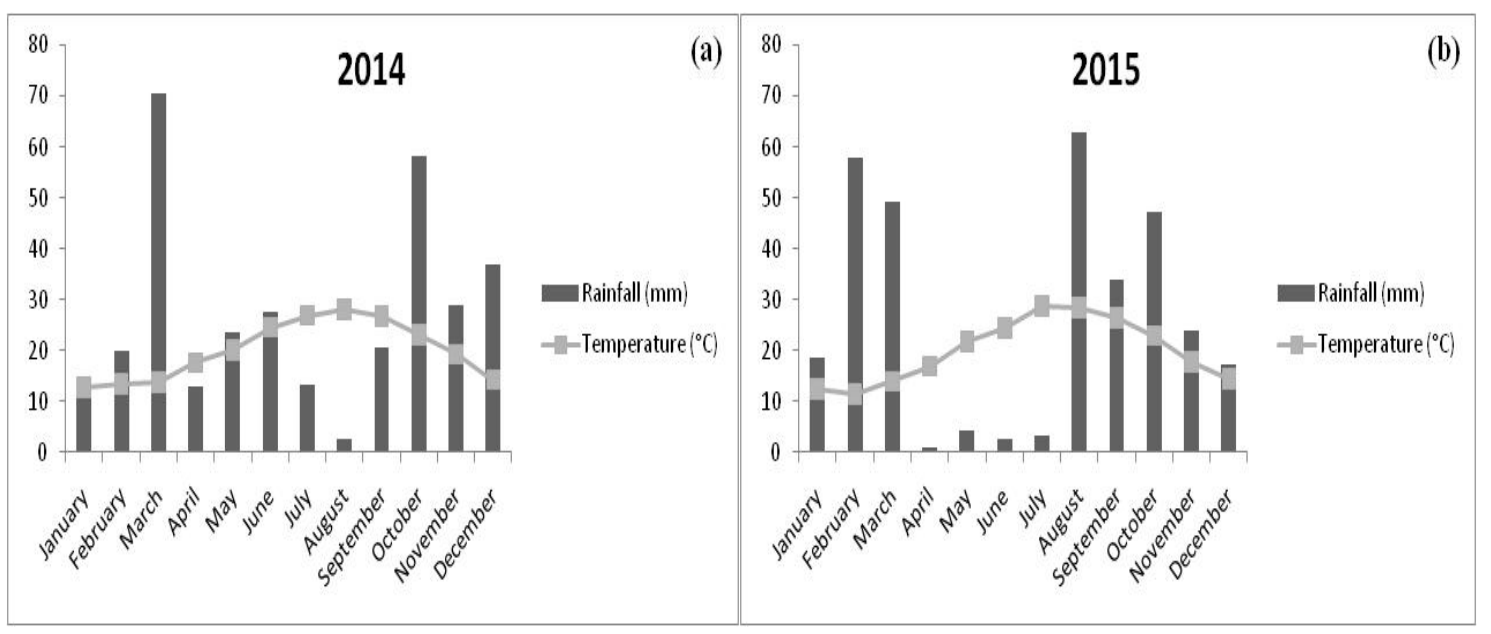

Figure 1. Monthly Variations in temperature and rainfall during the studied years 2014 (a) and 2015 (b).

\section{Treatments and experimental design} following:

This work was focused on the annual application of six foliar treatments as

- CON: control without foliar application.

- T1: Azofol SR applied at 5\%. This is a formulation of urea formaldehyde used as a source of nitrogen; it combines nitrogen with a specific mineral balance to remove any aggression of foliar and improve the efficiency of nitrogen in the olive tree (Table 1). Foliar application consisted of two sprays: one before the start of vegetation and the other 10 days later.

- T2: Alcygol B2M applied at 2\%. This is a biostimulant which combines the marine vitality with boron, magnesium manganese and sulfur. It is highly concentrated in boron to improve the homogeneity and the quality of flowering and fruit setting. Foliar application consisted of two sprays: one before the entry on the flowering and the other 10 days later.

- TNi: Nectar intense, a biostimulant with a protein extract rich in calcium. Foliar application consisted of three sprays with 15 days interval, starting from fruit set. It was sprayed at $2 \mathrm{~L} / \mathrm{ha}$.

- T12: combination of T1 and T2.

- T12Ni: combination of T1, T2 and T12Ni.

These fertilizers (Table 2) were purchased from a French platform and fertilization's program was applied during two successive years.

Table 2. Mineral composition ((m/v): $\left.\mathrm{g} \mathrm{L}^{-1}\right)$ of the foliar fertilizers used.

\begin{tabular}{lcccccccccccc}
\hline Fertilizer & $\mathbf{N}$ & $\mathbf{P}_{\mathbf{2}} \mathbf{O}_{\mathbf{5}}$ & $\mathbf{K}_{\mathbf{2}} \mathbf{O}$ & $\mathbf{M g O}$ & $\mathbf{S O}_{\mathbf{3}}$ & $\mathbf{C a O}$ & $\mathbf{B}$ & $\mathbf{C u}$ & $\mathbf{F e}$ & $\mathbf{M n}$ & $\mathbf{M o}$ & $\mathbf{Z n}$ \\
\hline $\mathrm{T} 1$ & 355 & - & - & - & - & - & 0.215 & 0.085 & 0.5 & 0.53 & 0.02 & 0.41 \\
\hline $\mathrm{T} 2$ & - & - & - & 50 & 111 & - & 27 & - & - & 10 & - & - \\
\hline $\mathrm{TNi}$ & - & - & - & - & - & 160 & - & - & - & - & - & - \\
\hline
\end{tabular}


The experiment was designed as a randomized block. Treatments are randomly distributed. For each treatment, three trees were involved.

\section{Harvest and oil extraction}

Olive fruits were collected at harvest, with a maturity index ranged between 3 to 5 on a scale of 0 to 7 , during two crop seasons from three random locations in each plot. Each sample consisted of $2 \mathrm{~kg}$ of fruits per experimental tree and transported directly to the laboratory. Olives were cleaned from leaves and unhealthy fruits and oil extraction has been carried out within $24 \mathrm{~h}$ of harvest. Fruits were crushed with a hammer mill, then the paste was malaxed at about $25{ }^{\circ} \mathrm{C}$ for $30 \mathrm{~min}$ and then centrifuged in a two-phase decanter $(3,500 \mathrm{rpm}$ over $1 \mathrm{~min}$, at room temperature). After decantation and filtration, the oil samples were transferred into amber glass bottles and stored until analysis.

\section{Biochemical oil analysis}

Physicochemical characteristics. The physicochemical characteristics: free acidity (FA), expressed as \% oleic acid, peroxide value (PV), expressed as milliequivalents active oxygen (meq $\mathrm{O}_{2}$ ) kg-1 oil and extinction coefficients $\mathrm{K}_{232}$ and $\mathrm{K}_{270}$ were determined according to European Union standard methods (EEC Regulation 2568/91, 2013) and later modifications thereof as described in Tekaya et al. (2012).

Fatty acid composition. Was determined by a capillary gas chromatographic method described in EEC Regulation 2568/91. We followed the methods of Tekaya et al. (2012). Fatty acid methyl esters (FAMEs) were prepared by saponification/methylation with methanolic $\mathrm{KOH}$. Chromatographic separation was performed using an HP5890 gas chromatograph (Hewlett-Packard, Palo Alto, CA, USA) equipped with a CP-6173-SIL-88 capillary column (50 m x $0.25 \mathrm{~mm}$ ID and $0.2 \mu \mathrm{m}$ film thickness), an injector and flame ionization detector (FID) at a temperatures of $190{ }^{\circ} \mathrm{C}$ and $250{ }^{\circ} \mathrm{C}$, respectively. The oven temperature was $165^{\circ} \mathrm{C}$ and helium was used as carrier gas. The injected volume was $1 \mu \mathrm{L}$ and results were expressed as peak area relative percent.

Total polyphenols and ortho-diphenols contents. Were quantified colorimetrically (Montedoro et al., 1992). Phenolic compounds were isolated by double extraction of a solution of oil in methanol/Tween 20 mixture. Folin-Ciocalteu reagent was added to a suitable aliquot of the combined extracts, and the absorption of the solution at $765 \mathrm{~nm}$ was measured. Values are given as mg of Gallic Acid per kilogram $\left(\mathrm{kg}^{-1}\right)$ oil. Concerning ortho-diphenols, the colorimetric measurement was at $500 \mathrm{~nm}$, using $1 \mathrm{~mL}$ of a solution $\mathrm{HCl}(0.5 \mathrm{~N}), 1 \mathrm{~mL}$ of a mixture solution of $\mathrm{NaNO}_{2}(10 \mathrm{~g})$ and $\mathrm{NaMoO}_{4} .2 \mathrm{H}_{2} \mathrm{O}$ $(10 \mathrm{~g})$ in $100 \mathrm{~mL} \mathrm{H}_{2} \mathrm{O}$ and finally $1 \mathrm{~mL}$ of $\mathrm{NaOH}(1 \mathrm{~N})$ with $100 \mu \mathrm{L}$ of the methanolic extract. Results are given as mg of cafeic acid kg-1 oil (Tekaya et al., 2012).

Chlorophyll and carotenoids content. We have followed the methods of Tekaya et al. (2013). The total chlorophyll content was calculated at 630, 670 and $710 \mathrm{~nm}$, using carbon tetrachloride and a UV-visible spectrophotometer (Perkin Elmer Lambda 25) as follows (Kiritsakis, 1998):

$$
\text { Chlorophyll }(\mathrm{mg} / \mathrm{kg} \text { oil })=\frac{A 670-\left(\frac{A 680+A 710}{\mathrm{z}}\right)}{0.901 X L}
$$

Where $\mathrm{A}$ is the absorbance of the oil at the respective wavelength and $\mathrm{L}$ is the cell thickness (cm).

Braz. J. Biol. Sci., 2020, Vol. 7, No. 15, p. 3-18. 
The carotenoids content was determined as $\beta$-carotene and was measured with the same spectrophotometer at wavelengths between 440 and $480 \mathrm{~nm}$, according to the method previously described by Dhibi et al. (2012). They were expressed using the following equation:

$$
\beta \text {-carotene }=A_{\lambda \max } \times\left(10^{5} / 2,650\right)
$$

Where $\mathrm{A}_{\lambda \max }$ : maximum of absorption between 440 and $480 \mathrm{~nm}$.

\section{Statistical analysis}

All statistical values were calculated using the Statistical Package for Social Sciences (SPSS) program, release 21.0 for windows (SPSS, Chicago, IL, USA). Values are given as the mean \pm standard deviation of three measurements. Duncan's multiple range test was used to determine significant differences among data. The statistical significance level was fixed at $\mathrm{p} \leq 0.05$. Total polyphenols and ortho-diphenols were subjected to multivariate analysis using General Linear Model procedure, including two fixed factors (treatment and year), in order to check the effect of each factor and their interaction.

\section{Results}

\section{Physicochemical characteristics}

Physicochemical characteristics of the oil extracted during two successive years 2014 and 2015 were presented in the Table 3.

Table 3. Physiochemical characteristics of olive oil after foliar treatments.

\begin{tabular}{|c|c|c|c|c|c|}
\hline & Treatment & $\begin{array}{c}\text { Free Acidity } \\
\text { (\% Oleic } \\
\text { Acid) }\end{array}$ & $\begin{array}{c}\text { Peroxyde value } \\
\text { (meq } \mathrm{O}_{2} \mathrm{~kg}^{-1} \\
\text { Oil) }\end{array}$ & $\mathbf{K}_{\mathbf{2 3 2}}$ & $\mathbf{K}_{270}$ \\
\hline & Quality Standard & $\leq 0,8$ & $\leq 20$ & $\leq 2,5$ & $\leq 0,22$ \\
\hline \multirow{6}{*}{$\begin{array}{l}\text { Year } \\
2014\end{array}$} & $\mathrm{CON}$ & $0.75 \pm 0.07^{a}$ & $18.44 \pm 0.38^{\mathrm{a}}$ & $2.46 \pm 0.03^{a}$ & $0.14 \pm 0.04^{b}$ \\
\hline & $\mathrm{T} 1$ & $0.45 \pm 0.3^{\mathrm{a}}$ & $16.44 \pm 0.77^{a b c}$ & $2.43 \pm 0.02^{\mathrm{a}}$ & $0.21 \pm 0.01^{\mathrm{a}}$ \\
\hline & $\mathrm{T} 2$ & $0.79 \pm 0.41^{a}$ & $15.00 \pm 1.67^{c}$ & $2.47 \pm 0.01^{\mathrm{a}}$ & $0.21 \pm 0.03^{a}$ \\
\hline & $\mathrm{T} 12$ & $0.54 \pm 0.04^{\mathrm{a}}$ & $16.00 \pm 0.67 \mathrm{bc}$ & $2.44 \pm 0.03^{a}$ & $0.14 \pm 0.03^{b}$ \\
\hline & $\mathrm{TNi}$ & $0.53 \pm 0.07^{a}$ & $17.33 \pm 1.15^{\mathrm{ab}}$ & $2.46 \pm 0.01^{\mathrm{a}}$ & $0.13 \pm 0.02^{b}$ \\
\hline & $\mathrm{T} 12 \mathrm{Ni}$ & $0.68 \pm 0.11^{\mathrm{a}}$ & $18.00 \pm 1.33^{\mathrm{ab}}$ & $2.46 \pm 0.03^{a}$ & $0.21 \pm 0.01^{\mathrm{a}}$ \\
\hline \multirow{6}{*}{$\begin{array}{l}\text { Year } \\
2015\end{array}$} & $\mathrm{CON}$ & $0.32 \pm 0.07 \mathrm{bc}$ & $6.96 \pm 1.56^{\mathrm{cd}}$ & $2.29 \pm 0.12^{\mathrm{a}}$ & $0.17 \pm 0.02^{b}$ \\
\hline & $\mathrm{T} 1$ & $0.34 \pm 0.00^{\mathrm{b}}$ & $8.61 \pm 0.63^{b}$ & $2.27 \pm 0.18^{\mathrm{a}}$ & $0.18 \pm 0.01^{b}$ \\
\hline & $\mathrm{T} 2$ & $0.39 \pm 0.00^{\mathrm{a}}$ & $7.74 \pm 0.75^{b c}$ & $2.35 \pm 0.07^{\mathrm{a}}$ & $0.18 \pm 0.01^{b}$ \\
\hline & T12 & $0.28 \pm 0.00^{\mathrm{c}}$ & $6.18 \pm 0.31^{d}$ & $2.32 \pm 0.13^{a}$ & $0.22 \pm 0.02^{a}$ \\
\hline & $\mathrm{TNi}$ & $0.34 \pm 0.00^{\mathrm{b}}$ & $5.95 \pm 0.02^{\mathrm{d}}$ & $2.31 \pm 0.12^{\mathrm{a}}$ & $0.23 \pm 0.00^{\mathrm{a}}$ \\
\hline & $\mathrm{T} 12 \mathrm{Ni}$ & $0.28 \pm 0.00^{c}$ & $16.67 \pm 0.00^{\mathrm{a}}$ & $2.33 \pm 0.15^{a}$ & $0.17 \pm 0.01^{b}$ \\
\hline
\end{tabular}

Values are means \pm Standard Deviation $(S D)(n=3)$. Means in the same column with different letters show statistically significant differences between treatments $(P \leq 0.05)$ according to Duncan's test within each year and for each parameter.

FA, indicating the percentage of oleic acid, noted the highest values on all treatment (treated trees and control trees) for the first year (2014). FA varied between 0.45 (T1 rich in nitrogen) and $0.79 \%$ of oleic acid (T2). No significant difference was 
shown between the treatments for this parameter. After the second year treatments, FA decreased significantly varying between 0.28 in the treatments T12 and T12Ni and $0.39 \%$ of oleic acid for the treatment T2.

$\mathrm{PV}$, measuring the degree of lipid oxidation varied between 15.00 for trees which received Alcygol B2M (T2) and $18.44 \mathrm{O}_{2} \mathrm{~kg}^{-1}$ oil (CON) for the first application. For the second year 2015, PV was lower ranging between 5.95 for the treatment $\mathrm{TNi}$ and 16.67 meq $\mathrm{O}_{2} \mathrm{~kg}^{-1}$ oil for the trees which received the combined treatment T12Ni (Azofol $\mathrm{SR}+$ Alcygol B2M + Nectar intense).

$\mathrm{K}_{232}$ varied from 2.43 (T1) to 2.47 (T2) and from 2.27 (T1) to 2.33 (T12Ni) for 2014 and 2015, respectively. For this parameter, no significant difference was found between the treatments for the two years. $\mathrm{K}_{270}$ varied from 0.13 (TNi) to 0.21 (T12Ni) and between 0.17 (CON and T12Ni) and 2.33 (T12Ni) for 2014 and 2015, respectively. Concerning the year 2014, the treatments T1, T2 and T12Ni noted the highest values (0.21) compared to the control treatment (0.14) and these differences were significant.

For 2015, the trees which received Azofol and Alcygol B2M treatment (T12) and Nectar intense (TNi) noted $\mathrm{K}_{270}$ values equal to 0.22 and 0.23 , respectively. The control trees showed the lowest $K_{270}(0.17)$. A significant difference was found between the trees which received treatments $(\mathrm{T} 12, \mathrm{TNi})$ and $\mathrm{CON}$.

\section{Fatty acid composition}

For the fatty acid composition, the oil chromatographic analysis permitted the identification of the main fatty acids. The percentages of the fatty acids, the ratio oleic acid/linoleic acid (C18:1/C18:2), saturated fatty acids (SAFA), unsaturated fatty acids (UFA), monounsaturated fatty acids (MUFA) and polyunsaturated fatty acids (PUFA) and the ratio MUFA/PUFA were determined for the year 2014 (Table 4).

Table 4. Fatty acid composition (\% by weight of total FAMEs) of olive oil after foliar application of different treatments during the first year 2014.

\begin{tabular}{|l|c|c|c|c|c|c|}
\hline Fatty Acid & CON & T1 & T2 & T12 & TNi & T12Ni \\
\hline C16:0 & $17.88 \pm 0.77^{\mathrm{ab}}$ & $17.68 \pm 0.43^{\mathrm{ab}}$ & $17.93 \pm 1.00^{\mathrm{ab}}$ & $17.42 \pm 0.54^{\mathrm{ab}}$ & $16.69 \pm 0.63^{\mathrm{b}}$ & $18.68 \pm 0.54^{\mathrm{a}}$ \\
\hline C18:1 & $54.63 \pm 1.19^{\mathrm{bc}}$ & $55.28 \pm 0.05^{\mathrm{b}}$ & $55.32 \pm 1.65^{\mathrm{b}}$ & $52.12 \pm 0.35^{\mathrm{cd}}$ & $58.37 \pm 0.59^{\mathrm{a}}$ & $51.42 \pm 3.40^{\mathrm{d}}$ \\
\hline C18:2 & $20.28 \pm 0.61^{\mathrm{bc}}$ & $19.60 \pm 0.59^{\mathrm{c}}$ & $19.90 \pm 0.57^{\mathrm{c}}$ & $22.60 \pm 0.34^{\mathrm{a}}$ & $17.31 \pm 0.69^{\mathrm{d}}$ & $22.08 \pm 2.53^{\mathrm{ab}}$ \\
\hline C18:3 & $0.88 \pm 0.03^{\mathrm{a}}$ & $0.92 \pm 0.05^{\mathrm{a}}$ & $0.87 \pm 0.12^{\mathrm{a}}$ & $0.97 \pm 0.08^{\mathrm{a}}$ & $0.92 \pm 0.07^{\mathrm{a}}$ & $0.92 \pm 0.02^{\mathrm{a}}$ \\
\hline C18:1/C18:2 & $2.70 \pm 0.14^{\mathrm{bc}}$ & $2.82 \pm 0.09^{\mathrm{b}}$ & $2.78 \pm 0.17^{\mathrm{b}}$ & $2.31 \pm 0.03^{\mathrm{c}}$ & $3.38 \pm 0.14^{\mathrm{a}}$ & $2.36 \pm 0.46^{\mathrm{c}}$ \\
\hline SAFA & $20.61 \pm 0.53^{\mathrm{ab}}$ & $20.26 \pm 0.48^{\mathrm{ab}}$ & $20.33 \pm 0.92^{\mathrm{ab}}$ & $20.17 \pm 0.86^{\mathrm{ab}}$ & $19.62 \pm 0.96^{\mathrm{b}}$ & $21.26 \pm 0.59^{\mathrm{a}}$ \\
\hline UFA & $79.39 \pm 0.53^{\mathrm{ab}}$ & $79.74 \pm 0.48^{\mathrm{ab}}$ & $79.67 \pm 0.92^{\mathrm{ab}}$ & $79.83 \pm 0.86^{\mathrm{ab}}$ & $80.38 \pm 0.96^{\mathrm{a}}$ & $78.74 \pm 0.59^{\mathrm{b}}$ \\
\hline MUFA & $58.23 \pm 1.14^{\mathrm{bcd}}$ & $59.22 \pm 0.09^{\mathrm{b}}$ & $58.90 \pm 1.43^{\mathrm{bc}}$ & $56.26 \pm 0.70^{\mathrm{cd}}$ & $62.15 \pm 0.64^{\mathrm{a}}$ & $55.74 \pm 3.10^{\mathrm{d}}$ \\
\hline PUFA & $21.16 \pm 0.62^{\mathrm{bc}}$ & $20.51 \pm 0.54^{\mathrm{c}}$ & $20.77 \pm 0.54^{\mathrm{c}}$ & $23.56 \pm 0.29^{\mathrm{a}}$ & $18.23 \pm 0.65^{\mathrm{d}}$ & $23.00 \pm 2.52^{\mathrm{ab}}$ \\
\hline MUFA/PUFA & $2.75 \pm 0.14^{\mathrm{bc}}$ & $2.89 \pm 0.08^{\mathrm{b}}$ & $2.84 \pm 0.14^{\mathrm{b}}$ & $2.39 \pm 0.03^{\mathrm{c}}$ & $3.41 \pm 0.12^{\mathrm{a}}$ & $2.46 \pm 0.43^{\mathrm{c}}$ \\
\hline
\end{tabular}

Values are means \pm SD $(n=3)$. Means in the same row with different letters show statistically significant differences between treatments $(\mathrm{P} \leq 0.05)$ according to Duncan's test within each year and for each parameter. SFA, saturated fatty acids; UFA, unsaturated fatty acids; MUFA, monounsaturated fatty acids; PUFA, polyunsaturated fatty acids.

During the two crop seasons, the oleic acid (C18:1) was the main monounsaturated fatty acid in the olive oil. For the first crop season (2014), after one year of foliar fertilizers' application, C18:1 was ranging between $51.42 \%$ (T12Ni) and 58.37\% (TNi). linoleic acid (C18:2) ranged between $17.31 \%$ (TNi) and 22.60\% (T12). No significant 
difference between treatments observed for the linolenic acid (C18:3), and this latter seemed to increase with nitrogen, boron and nectar intense (T1, T12 and T12Ni). The percentages of this Acid were equal to $0.92,0.97$ and $0.92 \%$ for the treatments T1, T12 and $\mathrm{T} 12 \mathrm{Ni}$, respectively, while for the CON the percentage was equal to $0.88 \%$. The levels of $\mathrm{C} 18: 3$ were thus below $1.0 \%$, the limit set by the IOC. No significant difference also observed for the palmitic acid (C16:0), which was ranged from $16.69 \%$ (TNi) to $18.68 \%$ (T12Ni). Concerning the ratios C18:1/C18:2 and MUFA/PUFA, the values varied from 2.31 (T12) to 3.38 (TNi) and from 2.39 (T12) to 3.41 (TNi), respectively.

All the free fatty acids (FFA) showed significant difference after two years of foliar fertilization during the following year (2015) and they increased under all the treatments compared to the CON except for the C18:1, which decreased especially under the treatments $\mathrm{T} 2$ and $\mathrm{T} 12 \mathrm{Ni}$ and was equal to 57.39 and $57.38 \%$, respectively (Table 5 ). The same trend as the C18:1 was observed for the ratios C18:1/C18:2 and MUFA/PUFA. The levels of these ratios decreased with foliar fertilization and the lowest values are observed for the treatment T2 and were equal to 3.12 and 3.14 for C18:1/C18:2 and MUFA/PUFA, respectively.

Table 5. Fatty acid composition (\% by weight of total FAMEs) of olive oil after foliar application of different treatments during the second year 2015.

\begin{tabular}{|l|c|c|c|c|c|c|}
\hline Fatty Acid & CON & T1 & T2 & T12 & TNi & T12Ni \\
\hline C16:0 & $16.16 \pm 0.05^{\mathrm{e}}$ & $17.24 \pm 0.01^{\mathrm{bc}}$ & $17.44 \pm 0.12^{\mathrm{b}}$ & $16.76 \pm 0.38^{\mathrm{d}}$ & $17.01 \pm 0.27^{\mathrm{cd}}$ & $18.01 \pm 0.06^{\mathrm{a}}$ \\
\hline C18:1 & $63.48 \pm 0.22^{\mathrm{a}}$ & $59.74 \pm 0.04^{\mathrm{b}}$ & $57.39 \pm 0.10^{\mathrm{d}}$ & $59.41 \pm 0.14^{\mathrm{c}}$ & $59.60 \pm 0.28^{\mathrm{bc}}$ & $57.38 \pm 0.06^{\mathrm{d}}$ \\
\hline C18:2 & $13.73 \pm 0.04^{\mathrm{f}}$ & $16.21 \pm 0.03^{\mathrm{e}}$ & $18.39 \pm 0.03^{\mathrm{a}}$ & $17.09 \pm 0.18^{\mathrm{c}}$ & $16.40 \pm 0.08^{\mathrm{d}}$ & $17.75 \pm 0.05^{\mathrm{b}}$ \\
\hline C18:3 & $0.8 \pm 0.01^{\mathrm{d}}$ & $0.82 \pm 0.00^{\mathrm{c}}$ & $0.82 \pm 0.00^{\mathrm{c}}$ & $0.84 \pm 0.01^{\mathrm{b}}$ & $0.89 \pm 0.01^{\mathrm{a}}$ & $0.84 \pm 0.01^{\mathrm{b}}$ \\
\hline C18:1/C18:2 & $4.62 \pm 0.00^{\mathrm{a}}$ & $3.68 \pm 0.01^{\mathrm{b}}$ & $3.12 \pm 0.00^{\mathrm{f}}$ & $3.48 \pm 0.03^{\mathrm{d}}$ & $3.63 \pm 0.01^{\mathrm{c}}$ & $3.27 \pm 0.00^{\mathrm{e}}$ \\
\hline SFA & $19.47 \pm 0.25^{\mathrm{c}}$ & $20.41 \pm 0.04^{\mathrm{b}}$ & $20.48 \pm 0.12^{\mathrm{b}}$ & $17.70 \pm 0.37^{\mathrm{c}}$ & $20.14 \pm 0.34^{\mathrm{b}}$ & $21.09 \pm 0.05^{\mathrm{a}}$ \\
\hline UFA & $80.53 \pm 0.25^{\mathrm{a}}$ & $79.59 \pm 0.04^{\mathrm{b}}$ & $79.52 \pm 0.12^{\mathrm{b}}$ & $80.30 \pm 0.37^{\mathrm{a}}$ & $79.86 \pm 0.34^{\mathrm{b}}$ & $78.91 \pm 0.05^{\mathrm{c}}$ \\
\hline MUFA & $66.00 \pm 0.22^{\mathrm{a}}$ & $62.56 \pm 0.03^{\mathrm{b}}$ & $60.31 \pm 0.09^{\mathrm{c}}$ & $62.37 \pm 0.18^{\mathrm{b}}$ & $62.57 \pm 0.25^{\mathrm{b}}$ & $60.55 \pm 0.06^{\mathrm{c}}$ \\
\hline PUFA & $14.54 \pm 0.04^{\mathrm{f}}$ & $17.03 \pm 0.03^{\mathrm{e}}$ & $19.21 \pm 0.03^{\mathrm{a}}$ & $17.92 \pm 0.19^{\mathrm{c}}$ & $17.29 \pm 0.09^{\mathrm{d}}$ & $18.36 \pm 0.02^{\mathrm{b}}$ \\
\hline MUFA/PUFA & $4.54 \pm 0.01^{\mathrm{a}}$ & $3.67 \pm 0.01^{\mathrm{b}}$ & $3.14 \pm 0.00^{\mathrm{f}}$ & $3.48 \pm 0.03^{\mathrm{d}}$ & $3.62 \pm 0.01^{\mathrm{c}}$ & $3.30 \pm 0.01^{\mathrm{e}}$ \\
\hline
\end{tabular}

Values are means \pm SD $(n=3)$. Means in the same row with different letters show statistically significant differences between treatments $(\mathrm{P} \leq 0.05)$ according to Duncan's test within each year and for each parameter. SFA, saturated fatty acids; UFA, unsaturated fatty acids; MUFA, monounsaturated fatty acids; PUFA, polyunsaturated fatty acids.

\section{Total polyphenols and ortho-diphenols contents}

Total polyphenols content, an important parameter in olive oil quality due to their high antioxidant effects, were presented in the Figure 2 for the two years of experiment 2014 and 2015. Firstly, it was important to note that total polyphenols content was higher for all the treatments (Control and treatments) during the second crop season than during the first one. The values varied between 204.90 (T2 Ni) and $816.12 \mathrm{mg} \mathrm{kg}^{-1}$ of gallic acid (T1) and between 737.15 (T12Ni) and $1343.15 \mathrm{mg} \mathrm{kg}^{-1}$ of gallic acid (TNi) during 2014 and 2015, respectively. The increase of the total polyphenols content during the second year could be explained by the amount of rainfall received. The quantity of cumulated precipitation received during autumn (from September until harvest) was equal to 106.52 $\mathrm{mm}$ and $87.65 \mathrm{~mm}$ in 2014 and 2015 respectively (Table 1). Also it is important to mention that $90 \%$ of the autumnal rain quantity happened during October and November 2014 while only $61 \%$ of the cumulative rain occurred during this same period in 2015. Therefore the higher availability of water during the first crop season (2014) and especially during October and November, lead to lower total polyphenols content compared to the following year (2015). Polyphenols concentration increased significantly 
under the three simple treatments (T1), (T2) and (TNi) compared to the control (CON) (Figure 2a) for the first year 2014, the same trend is observed for the ortho-diphenols content, the main natural oxidants of olive oil (Figure 2b). Concerning the orthodiphenols, the values ranged between 163.11 mg Cafeic Acid kg-1 oil for the treatment (T12) and $359.98 \mathrm{mg}$ Cafeic Acid kg-1 oil for T1. Concerning the combined treatments, both total polyphenols and ortho-diphenols content decreased, but this variation was not significant compared to the CON.

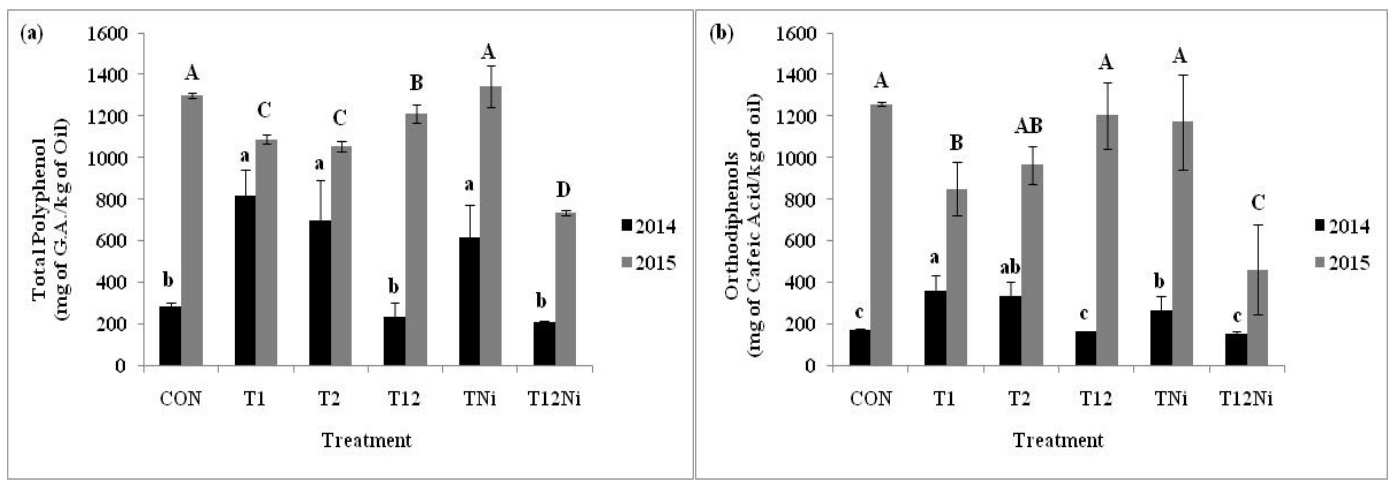

Figure 2. (a) Total polyphenols and (b) Orthodiphenols contents of olive oil after foliar application of different treatments. Different letters (tiny letters for 2014 and capital ones for 2015) indicate significantly different values at $\mathrm{P} \leq 0.05$ according to Duncan's test. Each point (represented as vertical bars), is the average of three values per treatment. Values are means \pm SD.

In 2015, total polyphenols content decreased in all treatments except for $\mathrm{TNi}$, where a slight increase has been noticed and was equal to 1,343.15 mg of Gallic Acid $\mathrm{kg}^{-1}$ oil whereas the content in the CON was equal to 1,300.61 mg of gallic acid kg-1 oil (Figure 2a). For the ortho-diphenols during the same year, a decrease was found in all the treatments with foliar fertilization compared to the CON where it was equal to 1,258.11 mg cafeic acid $\mathrm{kg}^{-1}$ oil. The significant difference was only observed under the treatments T1 (nitrogen based fertilizer) and T12Ni (Combined treatment) and the values were equal to $850.56 \mathrm{mg}$ cafeic acid $\mathrm{kg}^{-1}$ oil and $460.44 \mathrm{mg}$ cafeic acid $\mathrm{kg}^{-1}$ oil, respectively.

Results showed significant differences between years $(\mathrm{P} \leq 0.01)$ for total polyphenols and ortho-diphenols with higher values during the second crop season (2015) and a significant effect of the treatment. Also the interaction between the two factors (Year x Treatment) was significant on both parameters (Table 6). 
Table 6. Statistical analysis of the effect of year and fertilization treatment and their interaction on the total polyphenols and ortho-diphenols contents of olive oil.

\begin{tabular}{lcc}
\hline Factors & Total polyphenols & Ortho-diphenols \\
\hline Year & $468,255^{* *}$ & $342,298^{* *}$ \\
\hline Treatment & $25,943^{* *}$ & $10,000^{* *}$ \\
\hline Year x treatment & $18,629^{* *}$ & $10,319^{* *}$ \\
\hline
\end{tabular}

** Significant at $\mathrm{P} \leq 0.01$.

\section{Carotenoids and clorophyllic pigments}

As presented in the Table 7, the foliar fertilization didn't affect strongly the carotenoids and chlorophyllic pigments concentration during the first crop season 2014. In 2015, the concentration of those pigments seemed to be more sensitive to the foliar fertilization. The carotenoid pigment increased significantly under T1, T2, T12 and TNi, while the chlorophyllic pigment decreased under all the treatments compared to the CON.

Table 7. Effect of foliar fertilization on the Carotenoids and Clorophyllic pigments concentration in olive oil in 2014 and 2015.

\begin{tabular}{lcccc}
\hline \multirow{2}{*}{ Treatments } & \multicolumn{2}{c}{ Carotenoid (mg/kg) } & \multicolumn{2}{c}{ Chlorophyllic (mg/kg) } \\
\cline { 2 - 5 } & $\mathbf{2 0 1 4}$ & $\mathbf{2 0 1 5}$ & $\mathbf{2 0 1 4}$ & $\mathbf{2 0 1 5}$ \\
\hline C0N & $7.81 \pm 0.59 \mathrm{ab}$ & $8.86 \pm 0.60 \mathrm{~b}$ & $0.06 \pm 0.03 \mathrm{bc}$ & $0.73 \pm 0.00 \mathrm{a}$ \\
\hline T1 & $9.28 \pm 0.32 \mathrm{a}$ & $12.54 \pm 2.32 \mathrm{a}$ & $0.09 \pm 0.00 \mathrm{abc}$ & $0.41 \pm 0.02 \mathrm{c}$ \\
\hline T2 & $8.62 \pm 2.49 \mathrm{a}$ & $13.64 \pm 0.73 \mathrm{a}$ & $0.10 \pm 0.07 \mathrm{ab}$ & $0.30 \pm 0.01 \mathrm{~d}$ \\
\hline T12 & $5.25 \pm 0.52 \mathrm{c}$ & $14.05 \pm 1.73 \mathrm{a}$ & $0.04 \pm 0.01 \mathrm{c}$ & $0.57 \pm 0.03 \mathrm{~b}$ \\
\hline TNi & $5.62 \pm 0.58 \mathrm{bc}$ & $12.96 \pm 2.25 \mathrm{a}$ & $0.13 \pm 0.01 \mathrm{a}$ & $0.57 \pm 0.05 \mathrm{~b}$ \\
\hline T12Ni & $7.12 \pm 1.26 \mathrm{abc}$ & $5.45 \pm 1.38 \mathrm{c}$ & $0.05 \pm 0.00 \mathrm{bc}$ & $0.40 \pm 0.00 \mathrm{c}$ \\
\hline
\end{tabular}

Results are shown as mean \pm SD $(n=3)$. Means in the same column with different letters show statistically significant differences between treatments ( $\mathrm{P} \leq 0.05)$ according to Duncan's test within each year and for each parameter.

\section{Discussion}

Olive oil quality parameters varied regarding the nature of the fertilizer (biostimulant or nitrogen fertilizer), the simple or combined use and finally the climatic conditions of the year of treatment.

Physicochemical characteristics were sensitive to fertilization except for the parameter $\mathrm{K}_{232}$ for both years and for the FA for the first year 2014. All the values of the physiochemical characteristics for all the treatments were below the limits established by the IOC (2011) for extra virgin olive oils (EVOOs). The olive oils are thus classified as 'Extra Virgin Olive Oil'. The nutrient-based fertilization seems not affect strongly these quality indices of olive oil as demonstrated by Jordão et al. (2010) and Marcelo et al. (2010).

Fatty acid composition was not strongly affected by the nutrient-based fertilization especially during the first crop season. These results are in accordance with those reported by Wiesman et al. (2002) and Tekaya et al. (2012), who showed that foliar application of nutrient mixture (nitrogen, phosphorus, potassium and boron) had no 
significant effects on the fatty acid profile of olive oil. It is important to mention that during the second crop season, the FFA were more sensitive to fertilization.

An exception was found for C18:3, which increased under nitrogen based treatment and this increment was significant during the second crop season 2015 explained by the cumulative effect of foliar fertilization during the two years of experiment. This result was in accordance with those of Tekaya et al. (2012) and Fernández-Escobar et al. (2006) which noted an increase in C18:3 with nitrogen applications.

A drop of C18:1 during the second crop season was noted. This tendency was in contradiction with the results of Chouliares et al. (2009) working on the effect of biostimulants based on seaweed extract who found an increased C18:1 level. The differences in varieties and the environmental conditions such as soil type and climate may explain this different tendency.

The ratios C18:1/C18:2 and MUFA/PUFA decreased which was in agreement with the findings of Dag et al. (2009) and Inglese et al. (2002) studying the effect of macronutrient $(\mathrm{N}, \mathrm{P}, \mathrm{K})$ on the olive oil quality.

Polyphenols were lower the first year of experiment related to high availability of water rain. Total polyphenols content were the highest during the second year explained by the low rain quantity. This result was corroborated by the result of Uceda et al. (2004); Tovar et al. (2001); Romero et al. (2002); Marsilio et al. (2006) and Fernández-Escobar et al. (2006) who registered low polyphenols content with high rainfalls recorded. In fact high polyphenols has been related to stress caused by water deficit conditions (Uceda et al., 2004). Therefore, the low quantities of total polyphenols could be explained by reduced PAL's activity (phenylalanine ammonialyase) during the post pit hardening (Morelló et al., 2005).

According the nature of foliar fertilization, the treatment T1 Azofol SR applied the first year of experimentation (2014) induced an increase like observed by Tekaya et al. (2012) with the application of the same fertilizer. High levels of phenolics in plants have been linked to limited nitrogen supply in another work realized by Waterman and Mole (1994).

The treatment T2 (marine vitality rich in boron) caused a significant increase during 2014 in total polyphenols content which was in contrast with the results of Tekaya et al. (2012). This could be explained by the fact that the experimentation is in the first year and it seems that the boron supply is still limited. A limited nitrogen supply or boron deficiency seems to be associated with higher levels of phenolics in the plant (Waterman and Mole, 1994; Ruiz et al., 1998).

On the other hand, the treatment $\mathrm{TNi}$, a biostimulant with a calcium base, induced also an increase in the total polyphenols concentration which corroborated the results of Dabbaghi et al. (2019) working on the same variety "Chemlali", who found that foliar fertilization with calcium increased significantly the total polyphenols content. Similar observations were noted for orthodiphenols following foliar fertilization which is related to the activity of PAL. This result in 2015 has confirmed the one of the first year 2014 and validated the positive effect of calcium on the concentration of total polyphenols. As reported by some researchers, foliar fertilization with calcium $\left(\mathrm{Ca}^{2+}\right)$ increased PAL, polyphenol oxidase activity (PPO), and peroxidase (POD) activities which causes the accumulation of phenols (Ruiz et al., 2003).

After two years of experimentation, in 2015, all the treatments induced a decrease in the total poplyphenols concentration with an exception for the treatment TNi (rich in calcium). Also Fernández-Escobar et al. (2006) and Dag et al. (2009) w noted a decrease in total polyphenols content with increasing availability of nitrogen. The cumulative effect of two years of nutrients spray, can explain the action of nitrogen which causes large changes in the activity of enzymes involved in the metabolism of phenols, such as phenylalanine

Braz. J. Biol. Sci., 2020, Vol. 7, No. 15, p. 3-18. 
ammonia-lyase (PAL), polyphenol oxidase (PPO) and peroxidase (POD). An hypothesis could explain our results which is the protein competition model (PCM) (Jones and Hartley, 1999). Phenylalanine is the common source of protein and phenolics and when nitrogen is available; it is converted preferentially into proteins rather than to polyphenols via PAL.

Also, the cumulative application of boron based fertilizer induced a decrease of total polyphenols like noticed in the treatments rich in boron T2, T12 and T12Ni. These results could be explained by a good nutritional level of the trees studied for this element in the end of the experiment. In an adequate level of boron, the PAL activity is decreased and biosynthesis of phenols is limited (Ruiz et al., 1998).

Carotenoids and chlorophyllic pigments were not very sensitive to the fertilization during the first crop season (2014). These results corroborate those of Fernández-Escobar et al. (2006), studying the effect of nitrogen treatments on the olive oil quality. However, in 2015 , more significant changes have been observed for these pigments under foliar sprays of nutrients.

\section{Conclusions}

Our results provided clear evidence that biostimulant fertilizers influenced clearly the olive oil parameters. This study demonstrated quantitative variations in the pool of the fatty acids composition. The biostimulant treatment based on a protein extract with a calcium base (TNi) increased significantly the percentage of the oleic acid as well as the ratios C18:1/C18:2 and MUFA/PUFA. Although the simple treatments with nitrogen (T1) and the treatment rich in boron (T2) induced an increase of the total polyphenols and ortho-diphenols contents during the first year. The simple treatment with a biostimulant TNi rich in calcium seems to have positive effect on the content in total polyphenols. Those results are of great importance and this study highlighted the relation between the mineral elements and the quality of the olive oil.

Thus the foliar fertilization can optimize the olive oil quality and opened new researches according the biostimulant fertilizers application to satisfy the nutritional needs of orchards, minimize the environmental impact of fertilization, obtain a high quality product and avoid systematic excessive application of fertilizers.

Therefore, further work is necessary to study the effect of these fertilizers on the crop yield, flowering behavior and fruit set of the olive trees treated. Also the study of the seasonal change of nutrients elements and their interaction during the year in different part of trees like fruits, leaves, and roots following foliar fertilization is crucial to determine the relationship between minerals and quality of products.

\section{Acknowledgements}

We are grateful to the team of the project VRR (Valorization of Research Results) (Natsub-Tunoil). We would like to express our sincere thanks to the members of Olive Tree Institute (Sousse, Tunisia) for the high contribution to this research and the high technicity for assistance during treatments and olive oil extraction. Our special thanks go also to the members of the Biochemical Laboratory, USCR Mass Spectrometry, LAB-NAFS / LR12ES05"Nutrition - Functional Foods and Vascular Health in the faculty of medicine (University of Monastir) for their big engagement that helped us to carry out the analysis of the olive oil and to the owner and the workers of the olive grove for their help during the field experimental work. 


\section{Conflicts of interest}

The authors declare that they have no conflicts of interest.

\section{References}

Cakmak, I.; Marschner, H. Increase in membrane permeability and exudation in roots of zinc deficient plants. Journal of Plant Physiology, v. 132, p. 356-361, 1988. https://doi.org/10.1016/S0176-1617(88)80120-2

Chouliaras, V.; Tasioula, M.; Chatzissavvidis, C.; Therios, I.; Tsabolatido, E. The effects of a seaweed extract in addition to nitrogen and boron fertilization on productivity, fruit maturation, leaf nutritional status and oil quality of the olive (Olea europaea L.) cultivar Koroneiki. Jounal of Science of Food and Agriculture, v. 89, p. 984-988, 2009. https://doi.org/10.1002/jsfa.3543

CIR - Commission Implementing Regulation. Amending regulation EEC No. 2568/91 on the characteristics of olive oil and olive-residue oil and on the relevant methods of analysis. Official Journal of the European Union, (EEC) No. 2568/91, No. 299/2013.

Covas, M. I.; Nyyssonen, K.; Poulsen, H. E.; Kaikkonen, J.; Zunft, H. J.; Kiesewetter, H.; Gaddi, A.; Torre, R.; Mursu, J.; Bäumler, H.; Nascetti, S.; Salonen, J. T.; Fitó, M.; Virtanen, J.; Marrugat, J. The effect of polyphenols in olive oil on heart disease risk factors: A randomized trial. Annals of International Medicine, v. 145, no. 5, p. 333-341, 2006. https://doi.org/10.7326/0003-4819-145-5-200609050-00006

Dabbaghi, O.; Tekaya, M.; Flamini, G.; Zouari, I.; S. El-Gharbi, S.; M’barki, N.; Laabidi, F.; Cheheb, H.; Attia, F.; Aïachi Mezghani, M.; Hammami, M.; Mechri, B. Modification of phenolic compounds and volatile profiles of Chemlali variety olive oil in response to foliar biofertilization. Journal of American Oil Chemical Society, v. 96, p. 585-593, 2019. https://doi.org/10.1002/aocs.12201

Dag, A.; Ben-David, E.; Kerem, Z.; Ben-Gal, A.; Erel, R.; Basheer, L.; Yermiyahu, U. Olive oil composition as a function of nitrogen, phosphorus and potassium plant nutrition. Journal of American Oil Chemical Society, v. 89, p.1871-1878, 2009. https://doi.org/ $10.1002 /$ jsfa.3664

Dhibi, M. ; Issaoui, M.; Brahmi, F.; Mechri, B.; Mnari, A.; Cheraif, I.; Skhiri, F.; Gazzah, N.; Hammami, M. Nutritional quality of fresh and heated Aleppo pine (Pinus halepensis Mill.) seed oil: Trans-fatty acid isomers profiles and antioxidant properties. Journal of Food Science and Technology, v. 51, p. 1442-1452, 2012. https://doi.org/10.1007/s13197012-0664-5

Erel, R.; Dag, A.; Ben Gal, A.; Schwartz, A.; Yermiyahu, U. Flowering and fruit set of olive trees in response to nitrogen, phosphorus and potassium. Journal of the American Society for Horticultural Science, v. 133, p. 639-647, 2008. https://doi.org/10.21273/ JASHS.133.5.639

EBIC - European Biostimulant Industry Council. Promoting the biostimulant industry and the role of plant biostimulants in making agriculture more sustainable. 2013. Available from: <http://www.biostimulants.eu/>. Accessed on: Jun. 20, 2019.

Fernández-Escobar, R.; Beltrán, G.; Sáchez-Zamora, M. A.; Garciá-Novelo, J.; Aguilera, M. P.; Uceda, M. Olive oil quality decreases with nitrogen over-fertilization. HortScience, v. 41, p. 215-219, 2006. https://doi.org/10.21273/HORTSCI.41.1.215

Braz. J. Biol. Sci., 2020, Vol. 7, No. 15, p. 3-18. 
Fernández-Escobar, R.; Antonaya-Baena, M. F.; Sánchez-Zamora, M. A.; Molina Soria, C. The amount of nitrogen applied and nutritional status of olive plants affect nitrogen uptake efficiency. Scientia Horticulturae, v. 167, p. 1-4, 2014. https://doi.org/10.1016/ j.scienta.2013.12.026

Giuffrè, A. M. Influence of cultivar and harvest year on triglyceride composition of olive oils produced in Calabria (Southern Italy). European Journal of Lipid Scence and Technology, v. 115, p. 928-934, 2013. https://doi.org/10.1002/ejlt.201200390

Giuffrè, A. M. Evolution of fatty alcohols in olive oils produced in Calabria (Southern Italy) during fruit ripening. Journal of Oleo Science, v. 63, p. 486-496, 2014. https://doi.org/ 10.5650/jos.ess13212

Inglese, P.; Gullo, G.; Pace, L. S. Fruit growth and olive oil quality in relation to foliar nutrition and time of application. Acta Horticulturae, v. 586, p. 507-509, 2002. https://doi.org/10.17660/ActaHortic.2002.586.105

International Olive Oil Council. Trade standard applying to olive oil and Olive pomace oils. COI/T.15/NC No 3/Rev. 8, Madrid, Spain, 2015.

Jasrotia, A.; Singh, R. P.; Singh, J. M.; Bhutami, V. P. Response of olive trees to varying levels of N and K fertilizers. Acta Horticulturae, v. 474, p.337-340, 1999. https://doi.org/ 10.17660/ActaHortic.1999.474.69

Jones, C. G.; Hartley, S. E. A protein competition model of phenolic allocation. Oikos, v. 86, p. 27-44, 1999. https://doi.org/10.2307/3546567

Jordão, P. V., Marcelo, M. E.; Lopes, J. I.; Lopes, S. P. A. Long term experiment on olive tree with nitrogen, phosphorus and limestone fertilization. Acta Horticulturae, v. 868, p. 313318, 2010. https://doi.org/10.17660/ActaHortic.2010.868.41

Kailis, S.; Harris, D. Producing table olives. Collingwood, Australia: National Library of Australia Cataloguing in Publication Entry, 2007.

Kiritsakis, A. Olive oil from the tree to the table. 2. ed. Trumbull, Connecticut, USA: Food and Nutrition Press, 1998.

Kunicki, E.; Grabowska, A.; Sekara, A.; Wojciechowska, R. The effect of cultivar type, time of cultivation, and biostimulant treatment on the yield of spinach (Spinacia oleracea L.). Folia Horticulturae, v. 22, p. 9-13, 2010. https://doi.org/10.2478/fhort-2013-0153

Mahmoud, T. Sh. M.; Mohamed, E. Sh. A.; El-Sharony, T. F. Influence of foliar application with potassium and magnesium on growth, yield and oil quality of "Koroneiki" olive trees. American Journal of Food Technology, v. 12, p. 209-220, 2017. https://doi.org/ 10.3923/AJFT.2017.209.220

Marcelo, M. E.; Jordão, P. V.; Matias, H.; Rogado, B. Influence of nitrogen and magnesium fertilization of olive tree 'Picual' on yield and olive oil quality. Acta Horticulturae, v. 868, p. 445-450, 2010. https://doi.org/10.17660/ActaHortic.2010.868.62

Marsilio, V.; d'Andria, R.; Lanza, B.; Russi, F.; Iannucci, E.; Lavini, A.; Morelli, G. Effect of irrigation and lactic acid bacteria inoculants on the phenolic fraction, fermentation and sensory characteristics of olive (Olea europaea L. cv. Ascolana tenera) fruits. Journal of Food Science and Technology, v. 86, p. 1005-1013, 2006. https://doi.org/10.1002/ jsfa. 2449

Montedoro, G. F.; Servili, M.; Baldioli, M.; Miniati, E. Simple and hydrolysable phenolic compounds in virgin olive oil. 1. Their extraction, separation, and quantitative and 
semiquantitative evaluation by HPLC. Journal of Agricultural and Food Chemistry, v. 40, p. 1571-1576, 1992. https://doi.org/10.1021/jf00021a019

Morales-Sillero, A., Jiménez, R.; Fernández, J. E.; Troncoso, A.; Beltrán, G. Influence of fertigation in 'Manzanilla de Sevilla' olive oil quality. HortScience, v. 42, p. 1157-1162, 2007. https://doi.org/10.21273/HORTSCI.42.5.1157

Morelló, J.-R.; Romero, M.-P.; Ramo, T.; Motilva, M.-J. Evaluation of L-phenylalanine ammonia-lyase activity and phenolic profile in olive drupe (Olea europaea L.) from fruit setting period to harvesting time. Plant Science, v. 168, p.65-72, 2005. https://doi.org/10.1016/j.plantsci.2004.07.013

Nicolaïew, N.; Lemort, N.; Adorni, L.; Berra, B.; Montorfano, G.; Rapelli, S.; Cortesi, N.; Jacotot, B. Comparison between extra virgin olive oil and oleic acid rich sunflower oil: Effects on postprandial lipemia and LDL susceptibility to oxidation. Annals Nutrition \& Metabolism, v. 42, p. 251-260, 1998. https://doi.org/10.1159/000012741

Pacheco, Y. M.; Lopez, S.; Bermudez, B.; Abia, R.; Muriana, F. J. Extra-virgin vs refined olive oil on postprandial hemostatic markers in healthy subjects. Journal of Thrombosis and

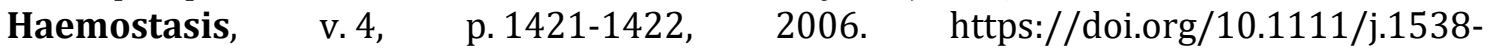
7836.2006.01963.x

Romero, M. P.; Tovar, M. J.; Girona, J.; Motilva, M. J. Changes in the HPLC phenolic profile of virgin olive oil from young trees (Olea europaea L. cv. Arbequina) grown under different deficit irrigation strategies. Journal of Agricultural and Food Chemistry, v. 50, p. 53495354, 2002. https://doi.org/10.1021/jf020357h

Ruiz, J. M.; Bretones, G.; Baghour, M.; Belakbir, A.; Romero, L. Relationship between boron and phenolic metabolism in tobacco leaves. Phytochemistry, v. 48, p. 269-272, 1998. https://doi.org/10.1016/S0031-9422(97)01132-1

Ruiz, J. M., Rivero, R. M.; López-Cantarero, I.; Romero, L. Role of $\mathrm{Ca}^{2+}$ in the metabolism of phenolic compounds in tobacco leaves (Nicotiana tabacum L.). Plant Growth Regulation, v. 4, p. 173-177, 2003. https://doi.org/10.1023/A:1027358423187

Scarmeas, N.; Stern, Y.; Tang, M. X.; Mayeux, R.; Luchsinger, J. A. Mediterranean diet and risk for Alzheimer's disease. Annals of Neurology, v. 59, p. 912-921, 2006. https://doi.org/10.1002/ana.20854

Servili, M.; Sordini, B.; Esposto, S.; Urbani, S.; Veneziani, G.; di Maio, I.; Selvaggini, R.; Taticchi, A. Biological activities of phenolic compounds of extra virgin olive oil. Antioxidants, v. 3, p. 1-23, 2014. https://doi.org/10.3390/antiox3010001

Tanou, G.; Ziogas, V.; Molassiotis, A. Foliar nutrition, biostimulants and prime-like dynamics in fruit tree physiology: New insights on an old topic. Frontiers in Plant Science, v. 8, 2017. https://doi.org/10.3389/fpls.2017.00075

Tekaya, M.; Mechri, B.; Bchir, A.; Attia, F.; Cheheb, H.; Daassa, M.; Hammami, M. Effect of nutrient-based fertilizers of olive trees on olive oil quality. Journal of Food Science and Technology, v. 93, p. 2045-2052, 2012. https://doi.org/10.1002/jsfa.6015

Tekaya, M.; Mechri, B.; Bchir, A.; Attia, F.; Chehab, H.; Daassa, M.; Hammami, M. Enhancement of antioxidants in olive oil by foliar fertilization of olive trees. Journal of the American Society for Horticultural Science, v. 90, p. 1377-1386, 2013. https://doi.org/ 10.1007/s11746-013-2286-0

Tovar, M. J.; Motilva, M. J.; Romero, M. P. Changes in the phenolic composition of virgin olive oil from young trees (Olea europaea L. cv. Arbequina) grown under linear irrigation

Braz. J. Biol. Sci., 2020, Vol. 7, No. 15, p. 3-18. 
strategies. Journal of Agricultural and Food Chemistry, v. 49, p. 5502-5508, 2001. https://doi.org/10.1021/jf0102416

Uceda, M.; Hermoso, M.; Aguilera, M. P. La calidad del aceite de olive. In: Barranco, D.; Fernández-Escobar, R.; Rallo, L. (Eds.). El cultivo del olivo. Madrid: Mundi-Prensa, 2004. p. 657-684.

Waterman, P. G.; Mole, S. Analysis of phenolic plant metabolites. Oxford: Blackwell Scientific, 1994.

Wiesman, Z.; Ronen, A.; Ankarion, Y.; Novikov, V.; Maranz, S.; Chpagain, B.; Abramovich, Z. Effect of Olive-Nutri-Vant on yield and quality of olives and oil. Acta Horticulturae, v. 594, p. 557-562, 2002. https://doi.org/10.17660/ActaHortic.2002.594.74

Zulaikha, R. I. Effect of foliar spray of ascorbic acid, Zn, seaweed extracts (sea) force and biofertilizes (EM-1) on vegetative growth and root growth of olive (Olea europaea L.) transplants cv. Hojiblanca. International Journal of Pure and Applied Sciences and Technology, v. 17, p. 79-89, 2013.

License information: This is an open-access article distributed under the terms of the Creative Commons Attribution License, which permits unrestricted use, distribution, and reproduction in any medium, provided the original work is properly cited. 